\title{
Mass aggregation of diatom blooms: Insights from a mesocosm study
}

\author{
ALICE L. ALLDREDGE,${ }^{*} \dagger$ CHRIS GOTSCHALK,$\dagger$ UTA PASSOW $\dagger$ \\ and ULF RIEBESELL $\dagger$
}

(Received 24 August 1994; in revised form 20 December 1994; accepted 8 January 1995)

\begin{abstract}
While the aggregation and mass settlement of diatoms at the termination of blooms results in significant export of carbon from the surface ocean, the mechanisms of bloom aggregation have been poorly understood. The aggregation of a multispecies diatom bloom was investigated under controlled conditions in a 1200 liter, nutrient-enriched, laboratory mesocosm in order to elucidate the parameters sufficient to accurately predict bloom aggregation. A diverse bloom of diatoms dominated by several species of Chaetoceros and Thalassiosira progressed through a classic pattern of exponential, stationary, and senescent phases in the mesocosm. Aggregates larger than $0.5 \mathrm{~mm}$ became detectable on the cighth day after inoculation, and aggregates $>1 \mathrm{~mm}$ increased exponentially from Day 10 onward producing the appearance of a mass aggregation event late on Day 10. The bloom aggregated sequentially with Thalassiosira doninating early aggregates and Chaetoceros dominating later ones. Chaetoceros resting spores formed only in aggregates. Aggregation was not linked to nutrient depletion or to the physiological state of the cells since the onset of aggregation and the mass aggregation event occurred 1 to 3 days prior to nutrient depletion and while carbon:nitrogen ratios of cells were still very low and growth rates high. Moreover, visible aggregates did not form in the mesocosm until cell abundances were considerably higher than abundances observed to aggregate in nature, suggesting that aggregation was not strongly linked to phytoplankton cell concentration. Complementary studies in this volume clarify the role of non-phytoplankton particles in aggregation of the mesocosm bloom. The mesocosm approach proved highly effective in producing an aggregating diatom bloom under controlled conditions.
\end{abstract}

\section{INTRODUCTION}

Evidence from sediment traps (Deuser and Ross, 1980; Honjo et al., 1982; Takahasi, 1986) and in-situ photographs of the sea floor (Billett $e t$ al., 1983) indicate that a significant proportion of surface-derived marine particulate matter sedimenting to the seafloor sinks as large aggregates of phytodetritus formed at the termination of phytoplankton blooms (Fowler and Knauer, 1986). This rapidly sinking phytoplankton often is dominated by relatively intact diatoms that reach the deep-sea floor within days of bloom termination without being ingested by zooplankton (Smetacek, 1985). Export of carbon from the surface ocean therefore, is closely linked to mechanisms of aggregation responsible for repackaging slowing sinking phytoplankton cells into large aggregates capable of rapid sedimentation (Jackson and Lochmann, 1992).

Despite extensive field evidence for aggregate formation at the termination of diatom

*Department of Biological Sciences, University of California, Santa Barbara, CA 93106, U.S.A.

Marine Science Institute. University of California, Santa Barbara, CA 93106, U.S.A. 
blooms (Krank and Milligan, 1988; Alldredge and Gotschalk, 1989; Riebesell, 1991; Kiørboe et al., 1994) the factors regulating aggregation are unclear. Aggregation of phytoplankton blooms results from the repetitive collision and subsequent attachment of cells and other particles to form larger aggregates. According to coagulation theory, the rate of aggregation is a function of the concentration and size distribution, sinking speeds, and surface stickiness of the individual particles present and of the intensity of the physical processes, especially shear, colliding them together (McCave, 1984).

In the only case where enough relevant parameters were measured to directly test coagulation theory in the field (Kiørboe et al., 1994), maximum phytoplankton concentrations and sedimentation rates in a Danish fjord were found to be consistent with a simple coagulation model of Jackson (1990). However, other coagulation models of physical aggregation and sedimentation in the ocean have required inclusion of high particle concentrations, relatively high shear, abundant non-phytoplankton background particles, or modification of particle contact rates in order to be consistent with observation (Jackson, 1990; Hill, 1992).

Thus, the factors most critical to predicting bloom aggregation in nature using coagulation theory remain unclear. Diatom species composition, the abundance of chainforming species, and the shapes of cells, including the presence of setae, may be significant (Jackson and Lochmann, 1992). A newly discovered class of abundant, sticky, transparent exopolymer particles (TEP) formed from polysaccharides exuded by diatoms may be necessary for aggregation of some blooms (Passow et al., 1994). The significance of phytoplankton cell surface stickiness, a major parameter in coagulation models (Kiørboe and Hansen, 1993), is still ambiguous as is the role of nutrient limitation in initiating aggregation (Riebesell, 1991; Bodungen et al., 1986).

The many biological and physical factors affecting aggregation rates have been difficult to elucidate in nature because natural blooms are open systems that are spatially heterogeneous, subject to widely varying turbulent regimes, advected horizontally, and grazed by zooplankton. Thus, it is difficult to sort unambiguously the mechanisms of aggregation in the field from competing processes such as consumption by animals, sedimentation, and bacterial degradation, which also alter particle size distributions.

In order to determine clearly the mechanisms controlling the aggregation of diatom blooms and subsequent mass sedimentation of carbon from surface waters, we and scveral of the authors in this special issue investigated the aggregation of a natural assemblage of diatoms under controlled conditions in a 1200 liter laboratory mesocosm. This approach allowed us to maintain a diverse, captive, ungrazed diatom bloom under known constant physical conditions, and to measure the relevant parameters necessary for evaluating aggregation using coagulation theory. Considerable previous research on blooms in mesocosms reveals that patterns of bloom development and sedimentation are surprisingly similar in all types of large enclosures regardless of nutrient addition or enclosure size (Bröckel, 1980; Gamble and Davies, 1980). However, aggregation processes have never been the focus of any mesocosm study.

Our combined results provide mechanistic explanations for the apparent mass flocculation and sedimentation of diatom blooms in nature and clarify the parameters necessary to predict export carbon flux from surface waters during phytoplankton blooms. In this paper we describe the experimental mesocosm itself, the progression of aggregation, and the changes in phytoplankton biomass, productivity, species composition, nutrient concentrations, and particle size distributions observed over the course of the bloom. 


\section{METHODS}

A bloom of a natural assemblage of diatom species was generated in a cylindrical, fiberglass tank $1.2 \mathrm{~m}$ high and $1.2 \mathrm{~m}$ in diameter placed in an environmental chamber set at $12^{\circ} \mathrm{C}$. The mesocosm was filled with 1150 liters of natural seawater from the Santa Barbara Channel which had been filtered through a large sand filter that was part of the university seawater system. An additional 50 liters of unfiltered seawater was added on Day 0 as an inoculum for the mesocosm. Samples were taken from the mesocosm through an external spigot that drew water approximately $10 \mathrm{~cm}$ from the mesocosm wall and $30 \mathrm{~cm}$ off the bottom.

The mesocosm was stirred at $2.6 \mathrm{rpm}$ with a $70 \mathrm{~cm}$ long plexiglass propeller containing 2 blades pitched at $30^{\circ}$ to the horizontal positioned $5 \mathrm{~cm}$ above the bottom (Fig. 1). While bubbling may be a preferred method for mixing mesocosms (Grice et al., 1980), a stirrer was necessary in this study because of the need to quantify and maintain a constant rate of energy dissipation throughout the study. Energy dissipation is a major term in coagulation models. The energy, being added to the water by stirring, was calculated as the product of the torque and the angular velocity of the stirring propeller. The mean energy dissipation rate generated by stirring was this energy input divided by the mass of the water in the mesocosm. The mean torque on the propeller was determined when the mesocosm volume was equal to that found at the beginning and end of the study using a torquemeter provided by Dr James Bonner (Texas A \& M University). While the rate of energy input to the tank was constant, the decreasing volume of the tank as samples were removed over the course of the study increased the energy dissipation rate per unit mass. The energy dissipation rate varied from 0.0137 to $0.0206 \mathrm{~cm}^{2} \mathrm{~s}^{-3}$ for tank volumes of 1200 and 800 liters, respectively.

High-nutrient additions were chosen to produce high cell abundances and insure detectable aggregation. Moreover, the continued availability of nutrients even in the presence of high particle concentration was expected to allow determination of the role of nutrient limitation as a factor triggering aggregation. Nutrients were added to mimic a rich upwelling system with initial concentrations of $46 \mu \mathrm{M} \mathrm{NO}, 45 \mu \mathrm{M} \mathrm{SiO}_{4}$, and $3 \mu \mathrm{M} \mathrm{PO}_{4}$. Sixty milliliters of trace metal stock (using ferric sequestrene as an iron source; Smith and Chaney, 1975), and $6 \mathrm{ml}$ vitamin stock (thyamin- $\mathrm{HCl}$, Biotin, $\mathrm{B}_{12}$; (Smith and Chaney, 1975)) were also added. Light was provided by 3 halogen lights set on a $14 \mathrm{~h}$ light: $10 \mathrm{~h}$ dark cycle to approximately match ambient conditions.

\section{Biological and chemical analyses}

All measurements were made on bulk seawater samples from the mesocosm collected through the spigot except those for phytoplankton size and abundance. Undisturbed seawater for phytoplankton was obtained by placing a polycarbonate tube $(50 \mathrm{~cm}$ long) into the mesocosm so that the top was $20 \mathrm{~cm}$ below the surface and corking each end by hand. Most parameters were measured twice each day, at 08:00 $\mathrm{h}$ and 16:00 h. Vertical profiles of temperature and salinity in the mesocosm were obtained with a Seabird CTD, Model SBE 19. A daily light profile was taken each morning with a Licor Model LI-185B light meter.

Triplicate $20-\mathrm{ml}$ samples for nutrients were filtered through a $0.45 \mu \mathrm{m}$ syringe filter directly into clean $25 \mathrm{ml}$ polyethylene vials and stored frozen at $-30^{\circ} \mathrm{C}$ until analysis by 

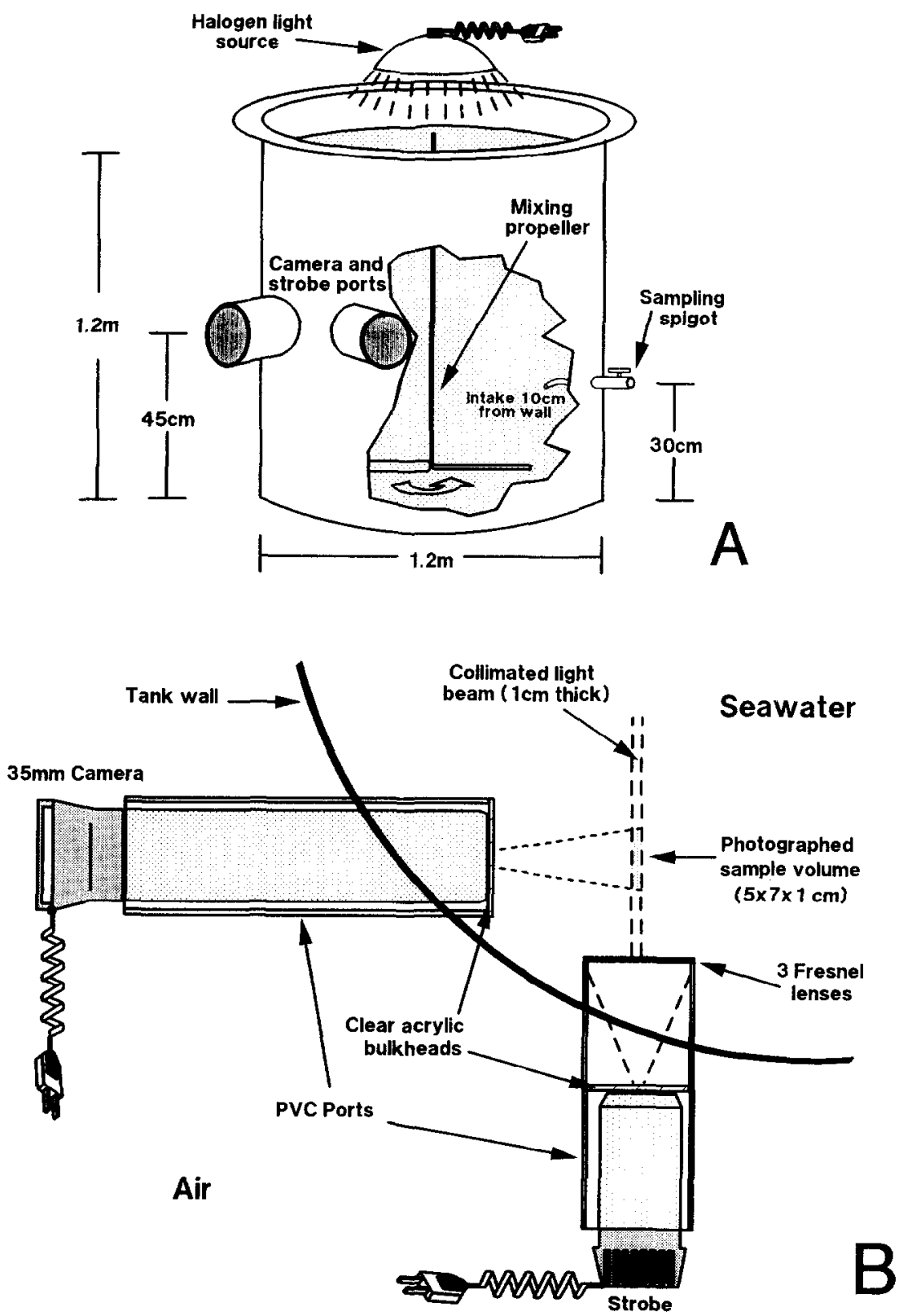

Fig. 1. Diagram of the 1400 liter mesocosm. (A) Entire mesocosm with cut away to show mixing propeller within. (B) Close-up of the camera and strobe configuration.

flow injection methods for nitrate, silicate, phosphate, and ammonium according to Johnson et al. (1985). Extracted chlorophyll $a$ and phaeopigments were measured on 5 replicate 10-ml samples by standard fluorometric methods (Parsons et al., 1984) using a Turner Model 111 fluorometer. Total particulate organic carbon and nitrogen were 
determined on 3 replicate samples of 500-ml each collected and analyzed on a Leeman Labs Model CE 440 CHN analyzer according to Sharp (1992). Dry mass was determined on 3 replicate $50-\mathrm{ml}$ samples filtered onto preweighed $25 \mathrm{~mm}$ polycarbonate filters $\left(0.45 \mu \mathrm{m}\right.$ pore size), dried at $80^{\circ} \mathrm{C}$, and reweighed on a Cahn electro-balance (Model 4600 ). The concentration of total dissolved inorganic carbon (DIC) and its compounds were calculated from $\mathrm{pH}$ (measured daily), alkalinity (measured at the beginning and end of the experiment as described in Parsons et al. (1984)), temperature, and salinity using the dissociation constants of Mehrbach et al. (1973).

Carbon fixation was determined by adding ${ }^{14} \mathrm{C}$-bicarbonate to 3 replicate $100-\mathrm{ml}$ samples for a final concentration of $0.26 \mu \mathrm{Ci} \mathrm{ml}^{-1}$. The samples were incubated at $13^{\circ} \mathrm{C}$ for $2 \mathrm{~h}$ at $125 \mu \mathrm{Em}^{-2} \mathrm{~s}^{-1}$ light. Following incubation, samples were filtered on $0.45 \mu \mathrm{m}$ pore size polycarbonate filters, placed in $10 \mathrm{ml}$ of Ecocint liquid scintillation fluid and counted on a LKB Liquid Scintillation Counter, Model 1217. Carbon fixation was corrected for dark fixation using two identical controls to which had been added $0.5 \mathrm{mM} \mathrm{DCMU} 93-(3,4-$ dichlorophenyl)-1,1, dimethylurea), a photosynthetic inhibitor (Legendre et al., 1983). Changing alkalinity and $\mathrm{CO}_{2}$ availability in the mesocosm over the course of the study were factored into carbon fixation calculations.

Bulk samples for phytoplankton enumeration were preserved in $2 \%$ borate buffered formalin. Phytoplankton particle numbers were determined microscopically on 2 replicate $10 \mathrm{ml}$ samples prepared using the Filter-Transfer--Freeze technique (Hewes and HolmHansen, 1983). Cells and chains were categorized primarily into size classes based on their length. Phytoplankton species identifications and total cell abundances were determined from 3 to $10-\mathrm{ml}$ preserved samples with an inverted microscope at $200 \times$ magnification using the Utermöhl method (Utermöhl, 1958). More than 500 cells each of Thalassiosira spp. and Chaetoceros spp. were counted in each chamber. The species composition of 3 to 4 aggregates per day collected on Days 11,12 , and 13 were also determined under $320 \times$ magnification. Diatoms were identified following Cupp (1943).

\section{Aggregate abundance}

The abundance and size distribution of aggregates in the mesocosm was obtained by photographing slabs of seawater $5.2 \times 7.7 \times 1 \mathrm{~cm}$ in size and $40 \mathrm{ml}$ in total volume using a Photosea $5000,35 \mathrm{~mm}$ camera with a $55 \mathrm{~mm}$ Nikon macrolens. The camera was directed into the interior of the mesocosm at a point $45 \mathrm{~cm}$ above the bottom through a flat transparent port. A Photosea $1500 \mathrm{~S}$ strobe firing through three superimposed fresnell lenses at a port $90^{\circ}$ to the camera produced a collimated slab of light in which particles were illuminated (Fig. 1). The camera was set at F-16 and synchronized with the strobe which had a $0.001 \mathrm{~s}$ flash duration and an output of $1500 \mathrm{~W} \mathrm{~s}^{-1}$. Twenty photographs were taken on T-max 400 black and white film at $08: 00 \mathrm{~h}$ and at 16:00 h each day. Lights over the mesocosm were extinguished during the 5 min required to obtain the photographs.

Particle sizes and abundances were quantified from the still film with a Megavision 1024 XM image analysis system. Each $35 \mathrm{~mm}$ exposure on the still camera negatives was scanned with a 1000 line Megavision video camera fitted with a $50 \mathrm{~mm}$ AF Nikor $1: 1.8$ lens and this video output analyzed by the computer. Thresholding was set by eye for each individual frame on the still film. Particles smaller than $120 \mu \mathrm{m}$ equivalent spherical diameter (ESD) could not be sized unambiguously and were not included. Data were binned into consecutive volume bins, each double the volume of the previous bin. 


\section{RESULTS}

A dense and highly diverse bloom of phytoplankton, dominated by diatoms, was generated in the mesocosm. The developing bloom altered the light and surface temperature conditions in the mesocosm slightly (Fig. 2). However, removal of samples daily also lowered the water level and increased the distance of the surface from the lights. Although temperature was relatively constant, about $12^{\circ} \mathrm{C}$, at $15 \mathrm{~cm}$ or deeper in the mesocosm, heating of the surface layer by the lights produced a thin, warmer surface layer which dissipated within 15 min when the lights went off. At the termination of the study the volume in the mesocosm had been reduced to 700 liters from the initial 1200 due to sampling, and salinity increased from an initial $33.2 \%$ to $34.3 \%$ as a result of some evaporation.

The general course of the bloom, as indicated by phytoplankton biomass and nutrient availability, followed a classic pattern discussed in detail below. Phytoplankton biomass increased exponentially during early log phase until the tenth day after inoculation. Large visible aggregates became abundant in late $\log$ phase from Days 10-11. Nutrients were depleted and biomass remained constant when the stationary phase was attained on Days 11-12. After Day 12 the bloom entered senescent phase and chl $a$ decreased.
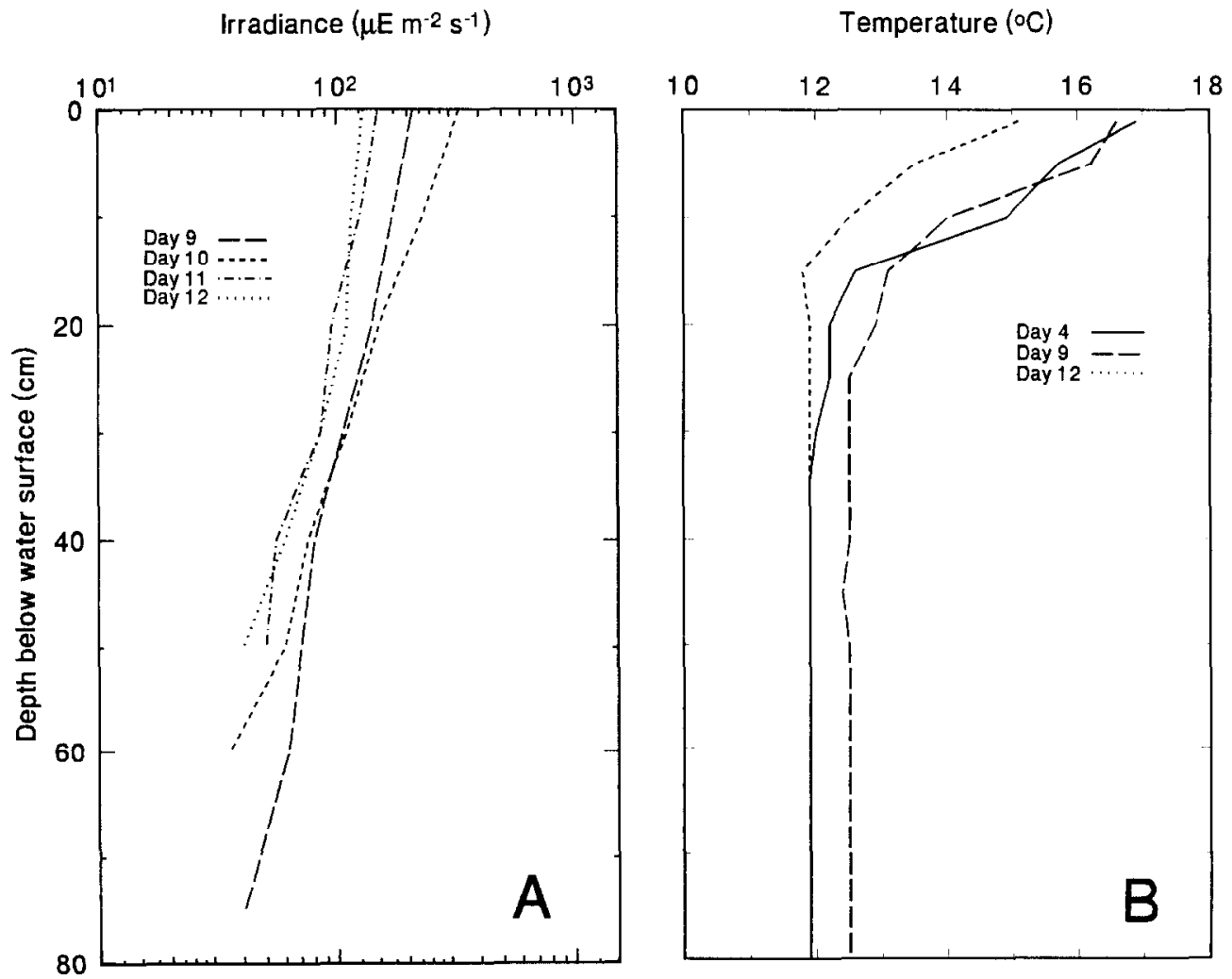

Fig. 2. Physical parameters in the mesocosm as a function of depth on selected days.

(A) Irradiance. (B) Temperature. 


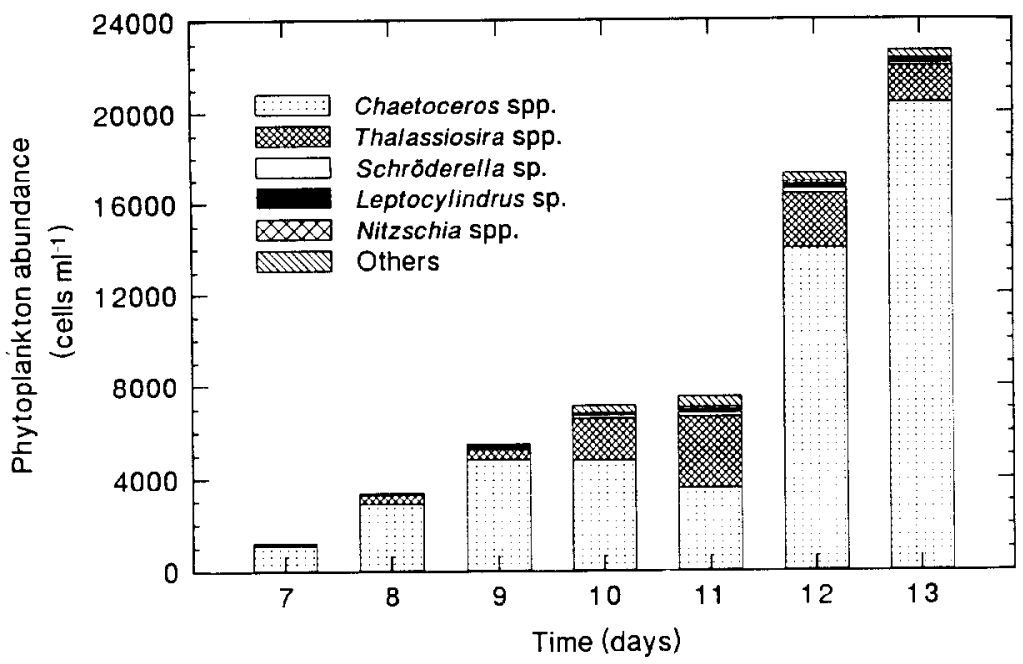

Fig. 3. Composition and cell abundance of dominant diatom genera in the bulk seawater over the course of the bloom.

\section{Phytoplankton composition, abundance, and production}

The mesocosm contained a rich and diverse community of phytoplankton, dominated by chain-forming diatoms especially the genera Chaetoceros, Thalassiosira, Schröderella, Leptocylindrus and Nitzschia all of which reached peak individual species concentrations $>150$ cells $\mathrm{ml}^{-1}$. Several species of the genus Chaetoceros, especially C. debilis, C. socialis and $C$. radicans, $C$. curvisetus, and $C$. compressus and Thalassiosira spp., especially $T$. decipiens and $T$. nordenskioldii made up more than $93 \%$ of the assemblage by cell number (Fig. 3). However, many other genera including Lauderia, Thalassionema, Grammatophora, Asterionella, Eucampia, Hemiaulus, Skeletonema, Cerataulina, Dityllum, Biddulphia and Rhizosolenia were also present at low abundances and were combined in the category 'other diatoms'. Some dinoflagellates and small naked flagellates also occurred (see Smith et al., 1995). Individual species were not monitored because the most abundant cells of both Chaetoceros and Thalassiosira could not be readily identified with certainty.

Cell abundance increased steadily from 1500 cells $\mathrm{ml}^{-1}$ on Day 7 to 23,500 cells per ml $\mathrm{ml}^{-1}$ on Day 13. However, the proportions of the two dominant genera varied over the study. Chaetoceros, the dominant genus in the mesocosm until Day 10, leveled in abundance between Day 9 and 11, while Thalassiosira spp. increased dramatically during this period. Chaetoceros spp. again increased in number on Days 12 and 13 (Fig. 3).

Phytoplankton were also enumerated as particles; i.e. as numbers of chains and single cells, since particles are the primary units involved in aggregation. Phytoplankton particle abundance and chlorophyll biomass increased exponentially reaching maximum levels on Day 11 (Fig. 4). This corresponded to the depletion of macronutrients (Fig. 5) on the same day and marked the beginning of the stationary phase. Since the nutrient addition was quite high, biomass in the mesocosm reached a high concentration of $168 \mu \mathrm{g}$ chl $a$ liter $^{-1}$. Although $\mathrm{SiO}_{3}$ remained limiting after Day 11, nitrogen generated as $\mathrm{NH}_{4}^{+}$through microbial processes in the mesocosm became available again during the stationary phase (Fig. 5). While stirring of the mesocosm prior to the senescent phase (Days 12-13) was 

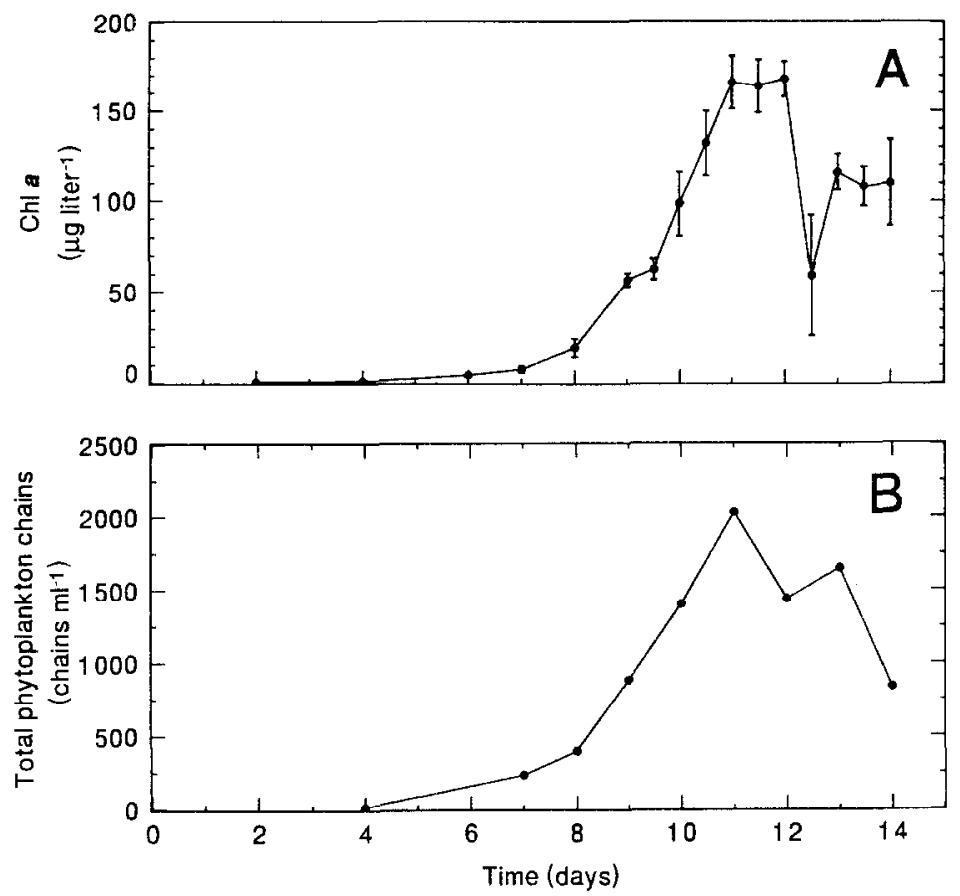

Fig. 4. Phytoplankton biomass and particle number. Bars represent $95 \%$ confidence intervals. (A) Chlorophyll $a$; (B) phytoplankton abundance expressed as discrete particles, i.e. numbers of chains and single cells.

adequate to keep cells and small aggregates in suspension, the abundance of large, heavy aggregates after Day 12 resulted in some sedimentation of material to the bottom of the mesocosm, accounting for some of the reduction in chl $a$ and total particle number on Days 12 and 13. Small sample size may also have caused undersampling once the bloom aggregated.

The size distributions of phytoplankton particles changed as the many chain-forming species grew (Fig. 6). Chains were longest on Day 11. Size distributions shifted back toward smaller size ranges on Day 12 (data not shown) and 13 as chains broke and cells became senescent (Fig. 6). Single cells made up a larger fraction of the total diatom population during the senescent phase (Day 12-13) than during the rest of the bloom.

Primary production increased exponentially, reaching a maximum of $190 \mu \mathrm{g} \mathrm{Cl}^{-1} \mathrm{~h}^{-1}$ on Day 9 [Fig. 7(A)]. Measurements made on Day 7 and 8 were anomalously low relative to cell abundance and chlorophyll, suggesting error in the measurements. These data are shown but not connected in the plots. Primary production per unit chlorophyll reached a maximum of $7 \mu \mathrm{g} \mathrm{C} \mu \mathrm{g}$ chl $a^{-1} \mathrm{~h}^{-1}$ on Day 6 before declining. Carbon specific primary production remained high through Day 9 and then declined. The very high phytoplankton biomass and carbon fixation occurring in the mesocosm as the bloom progressed resulted in substantial increases in $\mathrm{pH}$ from 8.4 to almost 9.0 between Day 8 and $13 . \mathrm{CO}_{2}$ concentrations also declined dramatically from Day 9 onward, reaching values of $1 \mu \mathrm{M}$ on Day 13 (Fig. 8).

Changes in phytoplankton biomass are mirrored by changes in particulate organic carbon and nitrogen, both of which also reached a maximum on Day 11. Carbon:nitrogen 

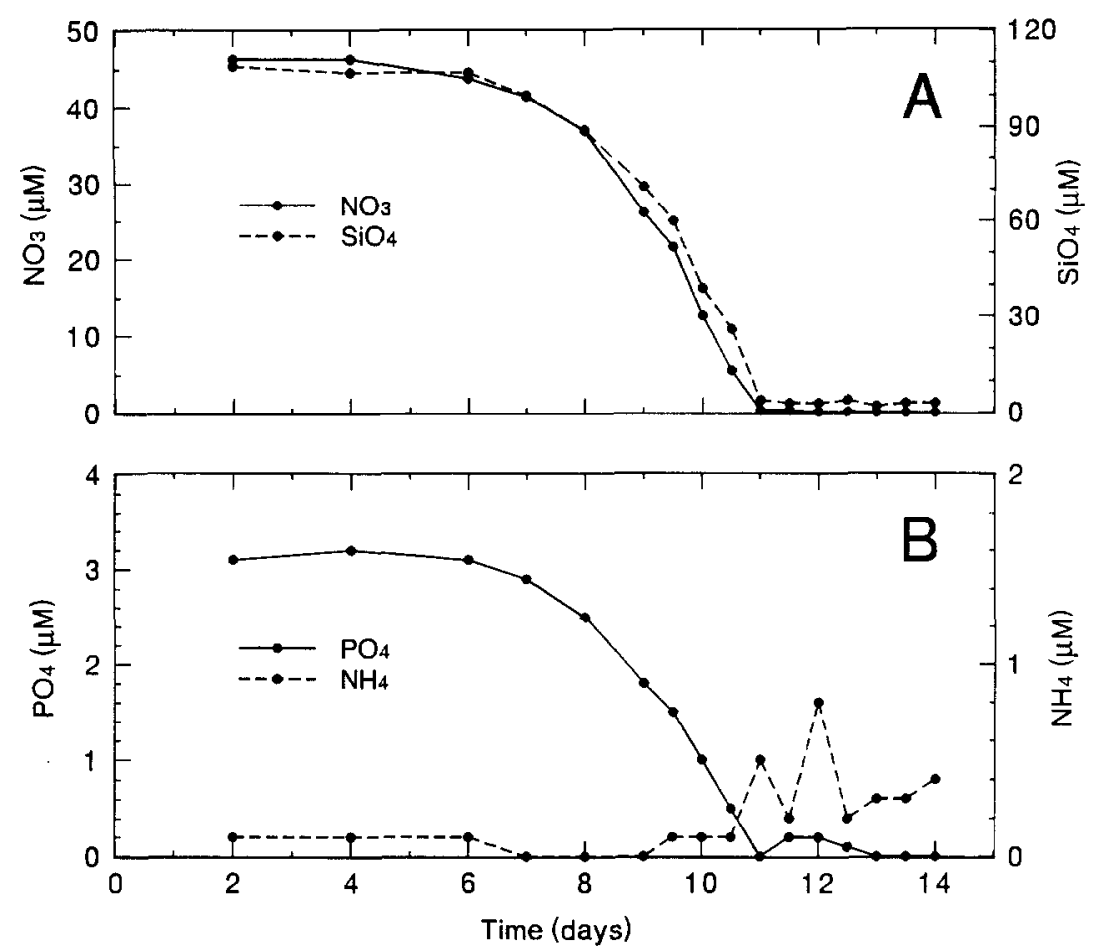

Fig. 5. Nutrient concentrations over the study. (A) Nitrate and silicate. (B) Phosphate and ammonium. Error bars were too small to be resolved graphically and are not shown.

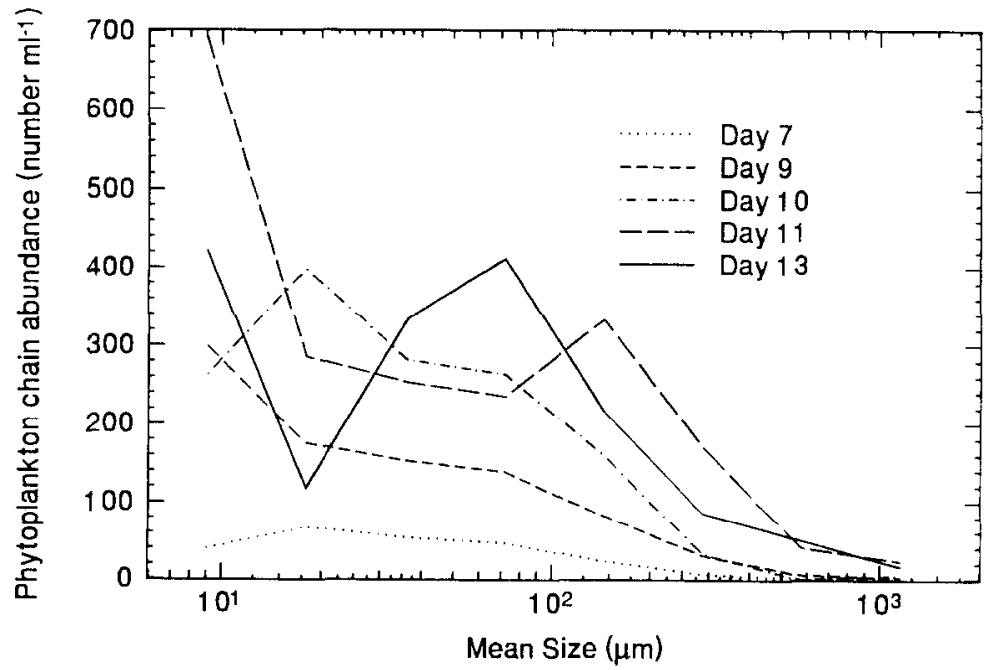

Fig. 6. Mean size distribution of phytoplankton particles (chains and single cells) on selected days as determined microscopically. 
A. L. Alldredge et al.
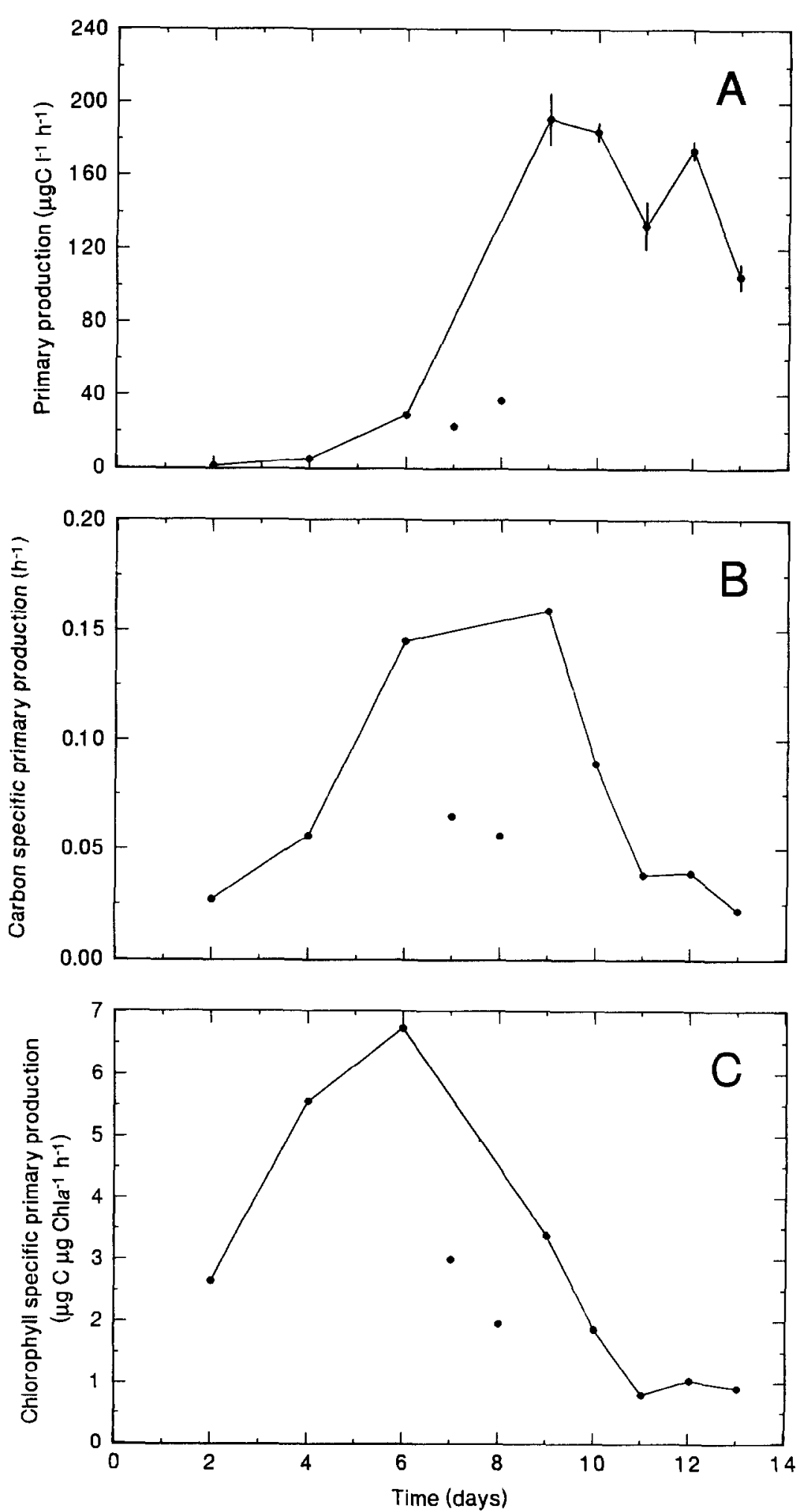
ratios remained fairly stable at about 4 until the beginning of the stationary phase on Day 11 when they began to increase rapidly, reaching 9 by Day 13 (Fig. 9).

\section{Aggregate abundance and composition}

Figure 10 presents binned, smoothed 3-dimensional plots of the size distributions of particles in the mesocosm obtained photographically over the course of the study. These are shown both as number abundance [Fig. 10(A)] and as total cumulative aggregate volume [Fig. 10(B)]. While the number of particles in size classes smaller than $500 \mu \mathrm{m}$ in equivalent spherical diameter $\left(1 \mathrm{~mm}^{3}\right.$ in volume $)$ increased exponentially as the bloom developed, larger aggregates did not appear consistently in high enough numbers to be detectable $\left(>1\right.$ liter $\left.^{-1}\right)$ until about Day 9. A dramatic increase in the concentration of larger size classes occurring between Day 10 and 10.5 and continuing from Day 10.5 to Day 11 is clearly visible in the cumulative volume plot [Fig. 10(A)] as a large shoulder. This apparently sudden appearance of numerous aggregates in the $>1 \mathrm{~mm}$ sizc classes may correspond to the flocculation 'event' leading to mass sedimentation noted in many field studies.

However, the dramatic increase in large aggregates from Day 10-11 is misleading. Plots of the abundance of aggregates $>0.5 \mathrm{~mm}$ indicate that formation of large flocs capable of rapid sedimentation actually progressed at a steady rate and began several days prior to Day 10.5 (Fig. 11). The abundance of $>0.5 \mathrm{~mm}$ aggregates increased steadily and exponentially starting on Day 8 . Aggregates $>1 \mathrm{~mm}$ in diameter became detectable on Day 10 and they also increased steadily and exponentially thereafter. However, because this increase in large aggregate abundance was exponential, the mesocosm appeared to undergo an aggregation 'event' on Days 10 to 11.

The aggregates produced in the mesocosm ranged up to $8 \mathrm{~mm}$ in length and consisted of diatoms intertwined with transparent exopolymer particles (TEP; see Passow and Alldredge, 1995). They were loose, porous, amorphous assemblages closely resembling natural marine snow in appearance.

Aggregates were composed primarily of species of Chaetoceros and Thalassiosira. However, the composition of aggregates changed as mass aggregation proceeded and did not mirror the composition of suspended diatoms in the surrounding water, suggesting sequential aggregation of the species present. Thalassiosira spp. aggregated more readily than Chaetoceros spp. and were always considerably enriched in aggregates over their composition in the surrounding seawater [Fig. 12(A)], Thalassiosira made up 55\% of the cells in aggregates on Day 11 [Fig. 12(B)]. By Day 13 Thalassiosira made up only $33 \%$ of the cells in aggregates, but because of the reduction of Thalassiosira in the surrounding seawater caused by its incorporation into aggregates, this genus was enriched 4.5 times in aggregates over its proportion in seawater. Chaetoceros gradually increased in proportion in aggregates as mass aggregation proceeded and composed $53 \%$ of total cells in aggregates by Day 13. However, Chaetoceros was always underrepresented in aggregates relative to its proportion in the surrounding water by a factor of about 2 [Fig. 12(A)].

Vegetative resting spores of Chaetoceros spp. were a predominant feature of aggregates

Fig. 7. Primary production of the bloom. (A) Rate of carbon fixation; (B) carbon fixation per unit carbon; (C) carbon fixation per unit Chl a (assimilation number). 


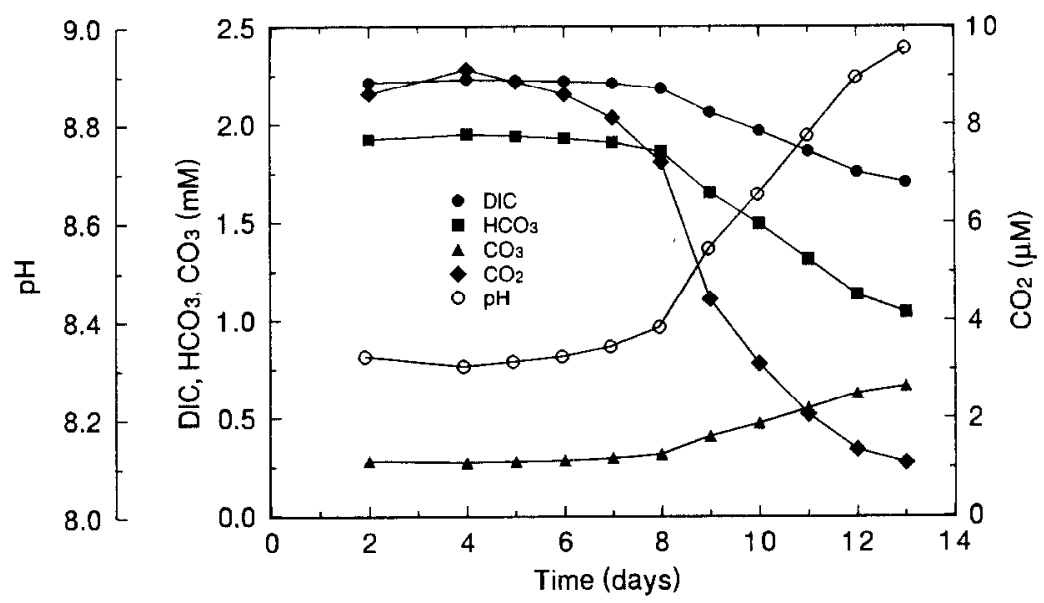

Fig. 8. pH, dissolved inorganic carbon (DIC) and its related compounds over the course of the experiment.

but were very rare among suspended cells [Fig. 12(B)]. Resting spores of $C$. debilis, $C$. curvisetus, $C$. compressus and $C$. socialis composed $18 \%$ of total cells and $60 \%$ of all the Chaetoceros cells present in aggregates on Day 11. Chactoceros spores still made up 15\% of aggregates by Day 13, but the percentage of Chaetoceros vegetative cells in aggregates had increased dramatically so that spores contributed only $28 \%$ to all Chaetoceros cells in aggregates by Day 13 .

\section{DISCUSSION}

The mesocosm proved to be highly effective in generating predictable aggregation of a diatom bloom. Mixing was adequate to keep particles in suspension and promote collision until the senescent phase when some large aggregates sedimented to the bottom. The bloom was highly diverse, with numerous species and genera present yielding a diatom composition similar to blooms common off the coast of southern California (Cupp, 1943) and in other mesocosm studies (Gamble and Davies, 1980). Chaetoceros spp. is a common component of aggregating diatom blooms in nature (Riebesell, 1991; Alldredge and Gotschalk, 1989; Passow et al., 1994) as is Thalassiosira spp. (Riebesell, 1991), Nitzschia (Alldredge and Gotschalk, 1989; Stachowitsch, 1990), and Skeletonema costatum (Riebesell, 1991; Kiørboe et al., 1994). The bloom also developed in a classic fashion, undergoing rapid exponential growth and eventual entry into stationary phase with the depletion of major nutrients. The healthy condition of the bloom is clearly reflected in the low $\mathrm{C}: \mathrm{N}$ ratio of cells during log phase.

The high phytoplankton species diversity, health of the cells, natural progression of the bloom, concentrations of bacteria and protozoans typical of nutrient rich coastal California waters (Smith et al., 1995), and the natural appearance of aggregates produced in the mesocosm suggest that the mesocosm emulated the natural ocean well. An abundance of previous mesocosm studies has also documented development of healthy diatom blooms 

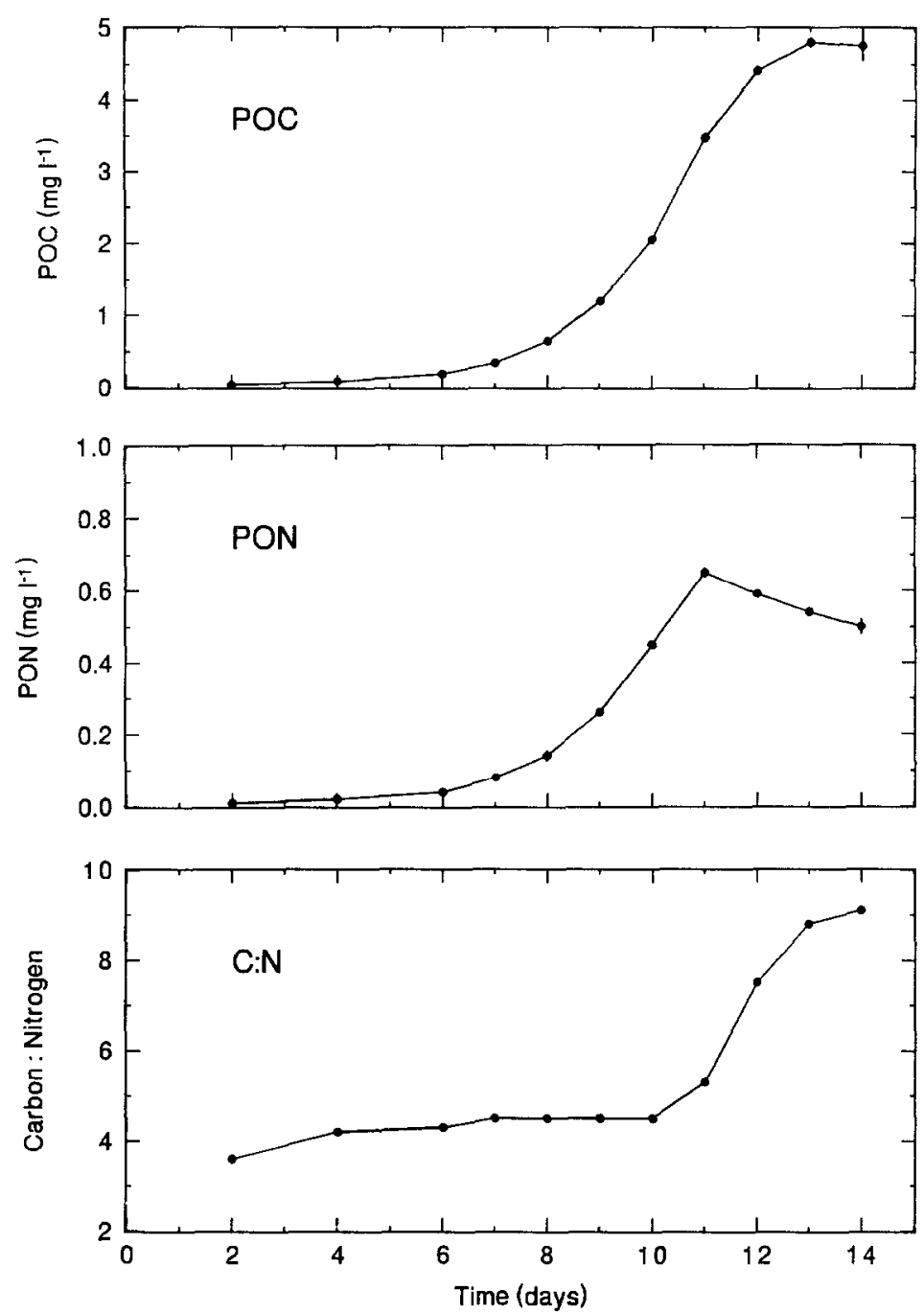

Fig. 9. Particulate organic matter in the tank. Error bars were too small to show. (A) Particulatc organic carbon; (B) particulate organic nitrogen; (C) carbon:nitrogen ratio.

(Davis et al., 1982; Harrison and Turpin, 1980) in enclosures, confirming the applicability of our results to natural systems.

Less typical of natural blooms, however, was the exposure to relatively high and constant shear. The rate of energy dissipation in the mesocosm of $10^{-2} \mathrm{~cm}^{2} \mathrm{~s}^{-3}$, was near the upper end of the range of $10^{-4}$ to $10^{-2} \mathrm{~cm}^{2} \mathrm{~s}^{-3}$ usually found in the upper mixed layer under high wind conditions (about $15 \mathrm{~m} \mathrm{~s}^{-1}$; Dillon and Caldwell, 1980; Oakey and Elliott, 1982). High shear would tend to accelerate aggregation processes since aggregation rate is a direct linear function of shear in coagulation models (McCave, 1984; Jackson, 1990). The unavoidable requirement that the mesocosm be stirred rather than bubbled also resulted in low surface gas exchange and possibly some breakage of diatoms chains.

The bloom was also unusual in that the phytoplankton biomass ultimately achieved was 

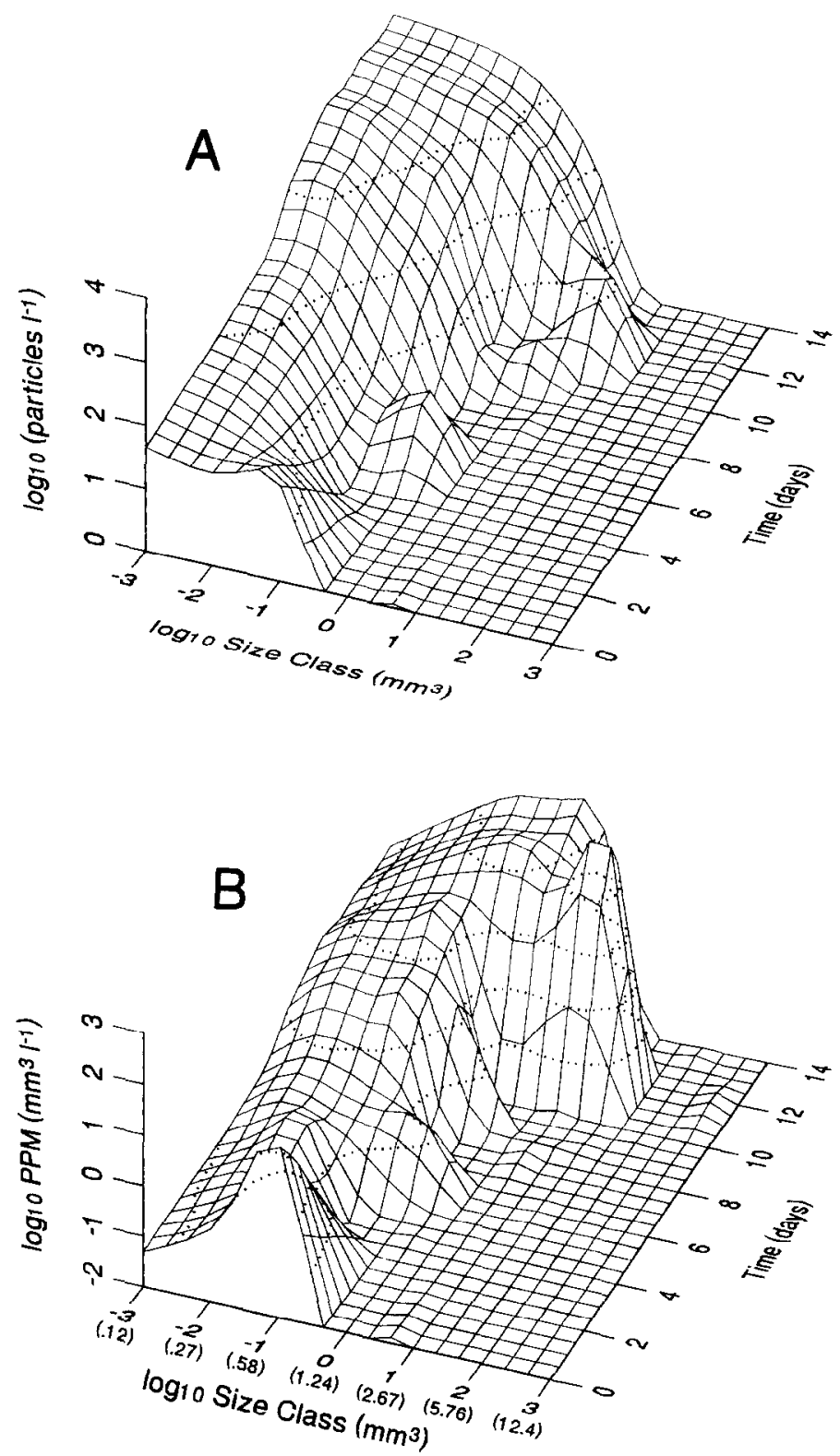

Fig. 10. Size distribution of all particles in the mesocosm larger than $120 \mu \mathrm{m}$ in diameter expressed as total particle volume (ppm) over the course of the study. (A) Mean particle abundance per size class; (B) mean total cumulative volume per size class. Numbers in parentheses are equivalent particle diameter.

near the maximum observed in natural systems. However, maximum chl $a$ values of $168 \mu \mathrm{g}$ $\mathbf{1}^{-1}$ in the mesocosm, though high, are still below some reported natural values such as the $638 \mu \mathrm{g}$ chl $a$ liter $^{-1}$ reported for a Skeletonema costatum bloom in Tokyo Bay (Han et al., 1992). Ccll abundances of 20,000 cells $\mathrm{ml}^{-1}$ are also high, but within the range observed in 


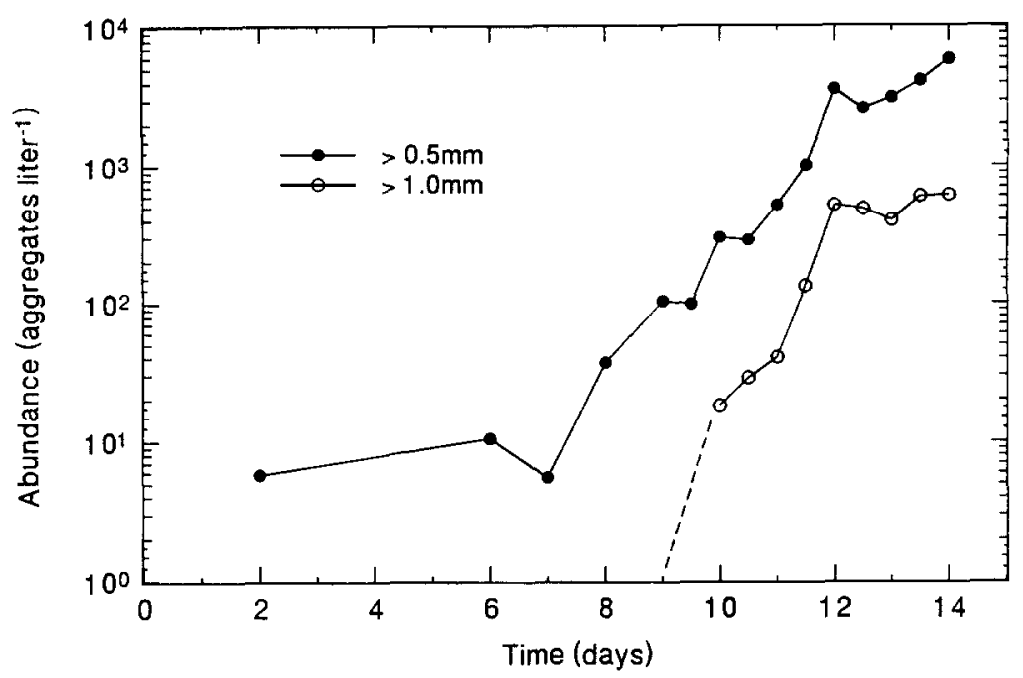

Fig. 11. Abundance of particles $>0.5 \mathrm{~mm}$ and $>1 \mathrm{~mm}$ in size over the course of the study as determined photographically through the mesocosm wall.

nature. Examples of higher natural values include cell abundances of 25,000 cells ml $^{-1}$ in

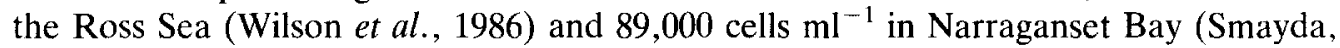
1957).

While limitation of macronutrients determined the maximum biomass of the bloom, the pause in the exponential growth of Chaetoceros spp. from Day 9 to 11 while Thalassiosira spp. continued to grow may have two alternate explanations. First, a Thalassiosira species may have exuded a substance that inhibited the growth of Chaetoceros spp. Second and most probable, is that a succession of a series of individual species of Chaetoceros and Thalassiosira may have occurred in the mesocosm, with different Chaetoceros species dominating before and after dominance of Thalassiosira. While we did not observe any obvious shifts in the dominant Chaetoceros species present, our data do not allow delineation of these explanations.

The mesocosm study reveals that some Chatoceros species form vegetative resting spores once aggregated and that resting spores can represent a significant proportion (up to $18 \%$ ) of cells in a diatom aggregate. Resting spores were not observed suspended in the surrounding seawater. Silver et al. (1978) also found that $100 \%$ of diatom resting spores present in the water column of Monterey Bay, California were in diatom aggregates. While most studies of natural diatom blooms have not commented on the presence of resting spores in aggregates, mass sedimentation of Chaetoceros resting spores has been reported from sediment traps studies (Pitcher, 1986). Moreover, while aggregation has not been measured in previous mesocosm studies, resting spores formed in mesocosms have been observed to sink significantly faster than cells (Davis et al., 1982), suggesting they may have been in aggregates.

Our mesocosm study suggests that spore formation may be significantly linked to aggregation, supporting the conclusions of Smetacek (1985) that aggregation and rapid sedimentation represents a transition to a resting stage in the life history of diatoms. The increased proportion of Chaetoceros resting spores in aggregates dominated by non- 

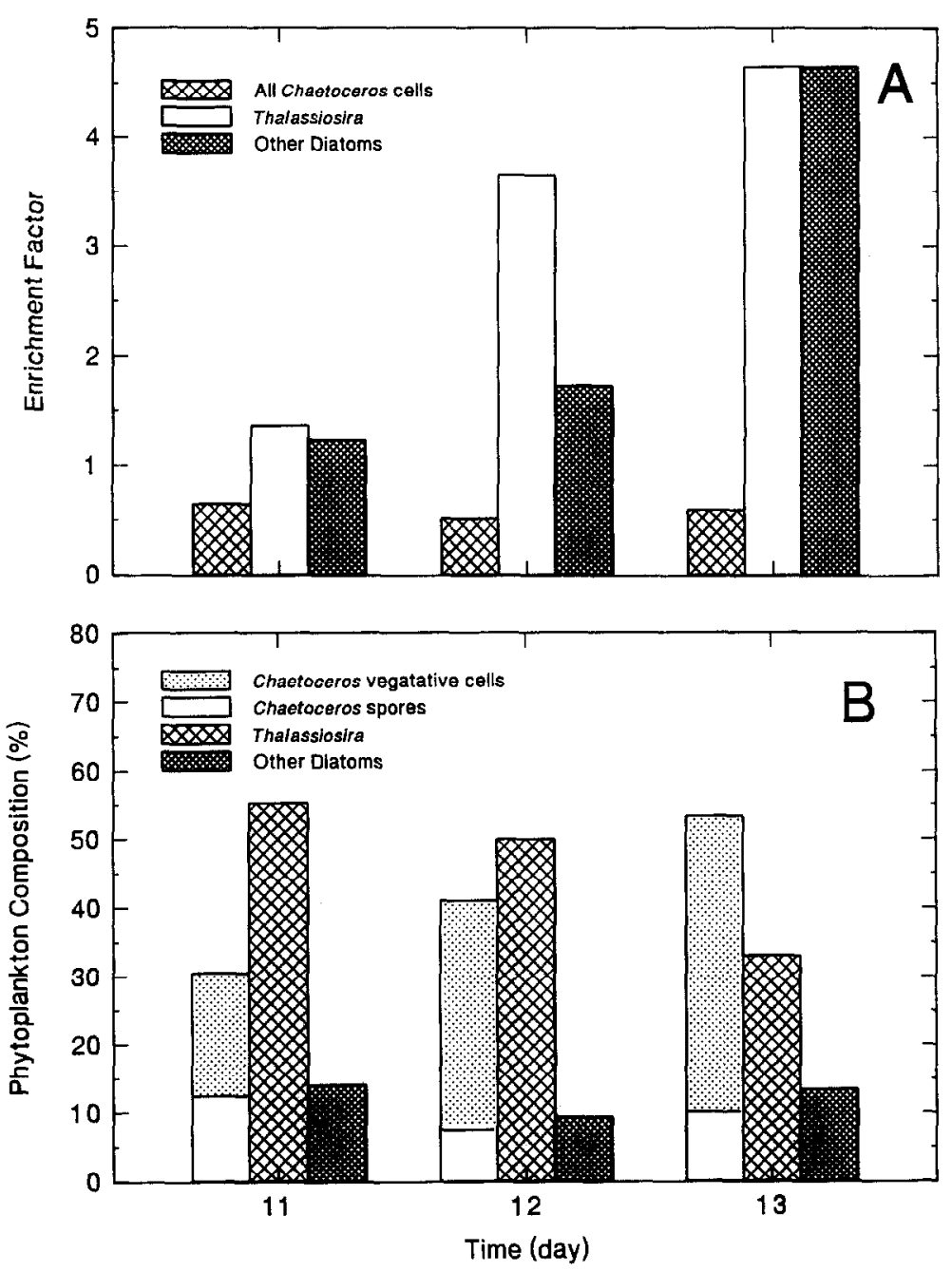

Fig. 12. Composition of large aggregates present in the mesocosm on Days 11,12 , and 13 . (A) Enrichment of diatoms in aggregates. The enrichment factor (EF) was calculated as the proportion of a taxon in aggregates divided by its proportion in the surrounding seawater. When $\mathrm{EF}=1$, the taxon was found in the same proportion in both aggregates and seawater. $\mathrm{EF}<1$ indicates that the taxon was depleted within aggregates relative to seawater; $\mathrm{EF}>1$ indicates that the taxon was enriched within aggregates relative to seawater. Both vegetative cells and resting spores are included under 'Chaetoceros'. (B) Taxonomic composition of aggregates. Total Chaetoceros is broken down into vegetative cells and resting spores.

Chaetoceros species also suggests that interspecific interactions or species specific chemical factors within the aggregates may trigger spore formation.

The results eliminate two factors previously suggested to play a role in the aggregation of diatom blooms. First, aggregation is not linked to nutrient depletion. Abundance of $>0.5$ $\mathrm{mm}$ particles increased from Day 8 forward and the rapid accumulation of $>1 \mathrm{~mm}$ particles occurred by Day 10, 1 to 3 days beforc nutrient limitation of the mesocosm. Nutrients were 
still very abundant during the aggregation 'event' on Day 10 to 10.5 . This result is consistent with observations of diatom blooms in nature. Diatom blooms in the Antarctic (Bodungen et al., 1986) and in the North Sea (Riebesell, 1991) have been observed to aggregate and sediment prior to nutrient depletion.

Second, aggregation is not closely linked to the physiological state of the cells. C:N ratios were constant and low (about 4 ), indicating that cells were in good health through Day 10. Carbon:nitrogen ratios from Day 11 onward began to increase indicating that the physiological state of the diatoms was deteriorating. This was 1-3 days after initiation of aggregation on Day 8 . The health of the cells is further supported by large increases in chl $a$ and cell and chain abundances between Day 10 and 11. Cells were healthy and continucd to grow exponentially well after the aggregation 'event' and the onset of aggregation.

Our results also indicate that aggregation is only weakly linked to phytoplankton abundance. The mesocosm bloom underwent a mass aggregation event on Day 10.5 at very high cell concentrations of $8000 \mathrm{ml}^{-1}$. Natural diatom blooms off California and elsewhere rarely exceed cell concentrations one tenth this value (Cupp, 1943) yet they also undergo mass aggregation (Alldredge and Gotschalk, 1989; Passow et al., 1994; Riebesell, 1991). With the exception of the bloom investigated by Kiørboe et al. (1994), where cell concentrations reached $10,000 \mathrm{ml}^{-1}$, most natural blooms appear to aggregate at abundances considerably lower than observed in the mesocosm. The mass aggregation of blooms at a range of cell concentrations an order of magnitude in extent suggests that phytoplankton cell abundance alone is insufficient to explain aggregation even at high rates of shear. Other factors appear necessary. Diatom species composition and the presence and nature of chain-forming species may explain some of the variability observed among different blooms. However, Passow et al. (1994) argue that transparent exopolymer particles (TEP) formed from polysaccharides exuded by diatoms are the major agents of aggregation in natural diatom blooms. Logan et al. (1995) present evidence indicating that TEP, rather than diatom cells, are the primary agents of aggregation in the mesocosm as well.

However, our data do indicate that diatom species can aggregate differentially. Thalassiosira spp. tended to aggregate differentially over vegetative Chaetoceros cells in the mesocosm, and Thalassiosira was always enriched in aggregates over its abundance in the surrounding water. These results are consistent with sequential aggregation of species observed in a natural bloom in the North Sea (Riebesell, 1991). How sequential and differential aggregation is accomplished is unknown. Chain size and shape may favor aggregation of some species above others through purely physical processes (Jackson and Lochmann, 1992). Characteristics of TEP also vary considerably between Thalassiosira and Chaetoceros spp. (Passow and Alldredge, 1994) and may result in differential aggregation (Passow and Alldredge, 1995). Finally, species specific changes in cell surface stickiness may alter aggregation rates, although these changes, if they occur, appear unrelated to depletion of macronutrients.

The mesocosm approach proved to be a highly effective means of investigating the causes and mechanisms of dialom bloom aggregation. Further papers in this volume clarify the role of other components of the aggregation story, including the role of cell surface stickiness, carbohydrates, TEP, bacteria and physical parameters.

Acknowledgements--The authors thank Lisa Dilling for technical assistance and Jim Bonner for use of the Torquemeter. Financial support was from the office of Naval Research (N00014-89-J3206). 


\section{REFERENCES}

Alldredge A. L. and C. C. Gotschalk (1989) Direct observations of the mass flocculation of diatom blooms: Characteristics, settling velocities and formation of marine snow. Deep-Sea Research, 36, 159-171.

Billett D. D. M., R. S. Lampitt, A. L. Rice and R. F. C. Mantoura (1983) Seasonal sedimentation of phytoplankton to the deep-sea benthos. Nature, 302, 520-522.

Bodungen, B. von, V. S. Smetacek, M. M. Tilzer and B. Zeitzschel (1986) Primary production and sedimentation during spring in the Antarctic Peninsula region. Deep-Sea Research, 33, 177-194.

Bröckel, K. von (1980) Sedimentation of phytoplankton cells within controlled experimental ecosystems following launching, and implications for further enclosure studies. In: Marine mesocosms, G. D. Grice and M. R. Reeve, editors, Springer, N.Y., U.S.A.

Cupp E. E. (1943) Marine plankton diatoms of the west coast of North America. Bulletin of Scripps Institution of Oceanography, 5, 1-238.

Davis C. O., J. T. Hollibaugh, D. L. R. Seibert, W. H. Thomas and P. J. Harrison (1982) Formation of resting spores by Leptocylindrus danicus (Bacillariophyceae) in a controlled experimental ecosystem. Journal of Phycology, 16, 296-302.

Deuser W. G. and E. H. Ross (1980) Seasonal change in the flux of organic carbon to the deep Sargasso Sea. Nature, 283, 364-365.

Dillon T. M. and D. R. Caldwell (1980) The Batchelor spectrum and dissipation in the upper ocean. Journal of Geophysical Research, 85, 1910-1916.

Fowler S. W. and G. A. Knauer (1986) Role of large particles in the transport of elements and organic compounds through the oceanic water column. Progress in Oceanography, 16, 147-194.

Gamble J. C. and J. M. Davies (1980) Application of enclosures to the study of marine pelagic systems. In: Marine mesocosm, G. D. Grice and M. R. Reeve, editors, Springer, N.Y., U.S.A.

Grice G. D., R. P. Harris, M. R. Reeve, J. F. Heinbokels and C. O. Davis (1980) Large-scale enclosed water-column ecosystems an overview of foodweb I. The final CEPEX experiment. Journal of the Marine Biological Association, 60, 401-414.

Han M. S., K. Furuya and T. Nemoto (1992) Species-specific productivity of Skeletonema costatum (Bacillariophyceae) in the inner part of Tokyo Bay. Marine Ecology Progress Series, 79, 267-273.

Harrison P. J. and D. H. Turpin (1980) The manipulation of physical, chemical, and biological factors to select species from natural phytoplankton communities. In: Marine mesocosms G. D. Grice and M. R. Reeve, editors, Springer, N.Y., U.S.A.

Hewes C. D. and O. Holm-Hansen (1983) A method for recovering nanoplankton from filters for identification with the microscope: The filter-transfer-freeze (FTF) technique. Limnology and Oceanography, 28, 389394.

Hill P. (1992) Reconciling aggregation theory with observed vertical fluxes following phytoplankton blooms. Journal of Geophysical Research, 97, 2295-2308.

Honjo S., S. I. Manganini and J. J. Cole (1982) Sedimentation of hiogenic matter in the deep ocean. Deep-Sea Research, 29, 609-625.

Jackson G. A. (1990) A model of the formation of marine algal flocs by physical coagulation processes. Deep-Sea Research, 37, 1197-1211.

Jackson G. A. and S. Lochmann (1992) Effect of coagulation on nutrient and light limitation of an algal bloom. Limnology and Oceanography, 37, 77-89.

Johnson K. S., R. L. Petty and J. Thomsen (1985) Flow injection analysis of seawater micronutrients. Advances in Chemistry Series, 209, 7-30.

Kiørboe T., C. Lundsgaard, M. Olsen and J. L. S. Hansen (1994) Aggregation and sedimentation processes during a spring phytoplankton bloom: A ficld experiment to test coagulation thcory. Journal of Marine Research, 52, 297-323.

Kiørboe T. and J. L. S. Hansen (1993) Phytoplankton aggregate formation: Observations of patterns and mechanisms of cell sticking and the significancc of exopolymcr matcrial. Journal of Plankton Research, 15, 993-1018.

Krank K. and T. G. Milligan (1988) Macroflocs from diatoms: In-situ photography of particles in Bedford Basin, Nova Scotia. Marine Ecology Progress Series, 44, 183-189.

Legendre L., S. Demers, C. M. Yentsch and C. S. Yentsch (1983) The ${ }^{14} \mathrm{C}$ methods: Patterns of dark $\mathrm{CO}_{2}$ fixation and DCMU correction to replace the dark bottle. Limnology and Oceanography, 28, 996-1003.

Logan B. E., U. Passow, A. L. Alldredge, H.-P. Grossart and M. Simon (1995) Rapid formation and 
sedimentation of large aggregates is predictable from coagulation rates (half-lives) of transparent exopolymer particles (TEP). Deep-Sea Research $I I, 42,215-238$.

McCave I. N. (1984) Size spectra and aggregation of suspended particles in the deep ocean. Deep-Sea Research, 31, 329-352.

Mehrbach C., C. H. Culberson, J. E. Hawley and R. W. Pythowicz (1973) Measurement of the apparent dissociation constants of carbonic acid in seawater at atmospheric pressure. Limnology and Oceanography, 18, 897-907.

Oakey N. S. and J. A. Elliot (1982) Dissipation within the surface mixed layer. Journal of Physical Oceanography, 12, 171-185.

Parsons T. R., Y. Maita and C. M. Lalli (1984) A manual of chemical and biological methods for seawater analysis. Pergamon Press, N.Y., 173 pp.

Passow U., A. L. Alldredge and B. E. Logan (1994) The role of particulate carbohydrate exudates in the flocculation of diatom blooms. Deep-Sea Research I, 41, 335-357.

Passow U. and A. L. Alldredge (1994) Distribution, size and bacterial colonization of transport exopolymer particles (TEP) in the ocean. Marine Ecology Progress Series, 113, 185-198.

Passow U. and A. L. Alldredge (1995) Aggregation of a diatom bloom in a mesocosm: The role of transparent exopolymer particles (TEP). Deep-Sea Research $I I, 42,99-109$.

Pitcher G. C. (1986) Sedimentary flux and the formation of resting spores of selected Chaetoceros species in the southern Benguela system. South African Journal of Marine Research, 4, 231-244.

Riebesell U. (1991) Particle aggregation during a diatom bloom. II Biological aspects. Marine Ecology Progress Series, 69, 281-291.

Sharp J. H. (1992) Total mass and particulate carbon, nitrogen, and phosphorus. In: Marine particles: Analysis and characterization, D. C. Hurd and D. W. Spencer, cditors, Geophysical Monograph 63, American Geophysical Union, pp. 87-91.

Silver M. W., A. L. Shanks and J. D. Trent (1978) Marine snow: Microplankton habitat and source of small-scale patchiness in pelagic populations. Science, 201, 371-373.

Smetacek V. S. (1985) Role of sinking in diatom life-history cycles: Ecological, evolutionary, and geological significance. Marine Biology, 84, 239-251.

Smayda T. J. (1957) Phytoplankton studies in lower Narraganset Bay. Limnology and Oceanography, 2, 342359.

Smith D. C., G. F. Steward, R. A. Long and F. Azam (1995) Bacterial mediation of carbon fluxes during a diatom bloom in a mesocosm. Deep-Sea Research $I I, 42,75-97$.

Smith W. L. and M. H. Chaney (1975) Culture of Marine Invertebrate Animals. Plenum Press, N.Y., pp. $29-60$.

Stachowitsch M., N. Fanuko and M. Richter (1990) Mucous aggregates in the Adriatic Sca: An overview of stages and occurrence. Marine Ecology, 11, 327-350.

Takahashi K. (1986) Seasonal fluxes of pelagic diatoms in the subarctic Pacific, 1982-1983. Deep-Sea Research, 33, 1225-1251.

Utermöhl H. (1958) Zur Vervollkommnung der quantitativen Phytoplankton-Methodik. Internationale Vereinigung für Theoretische und Angewante Limnologie, Mitteilung, 9, 1-38.

Wilson D. L., W. O. Smith, Jr and D. M. Nelson (1986) Phytoplankton bloom dynamics of the western Ross Sea ice edge. I. Primary productivity and species-specific production. Deep-Sea Research, 33, 1375-1387. 